\title{
HIPPURIC ACID IN THE URINE OF NORMAL BREAST-FED INFANTS *
}

SAMUEL AMBERG, M.D., AND J. H. MASON KNOX, JR., M.D.

BALTIMORE

The urine of the normal breast-fed infant is mainly distinguished by negative characteristics. This is a statement made by Mayerhofer ${ }^{1}$ in his recent paper. In this paper attention is called to the absence of such substances as glycuronic acid, indican, urobilin, etc., in the urine of these individuals. According to the same author some of the products normally encountered in the urine of adults, like the substances paired with glycocoll, namely, benzoic acid, etc., have not been made the subject of detailed investigation. With regard to the occurrence of hippuric acid in the urine of infants, only a few scanty references came to our notice. Marchand ${ }^{2}$ as well as Meissner and Shephard ${ }^{3}$ state that the occurrence of hippuric acid in the infant's urine is a well-known fact. Amberg and Morrill, 4 examining 260 c.c. of a mixed urine obtained from several healthy breast-fed infants, were unable to demonstrate the presence of free or combined benzoic acid. From the examination of this amount of urine of such low cencentration no definite conclusions could be drawn. It was therefore thought advisable to repeat the examination with a larger amount of urine. Thanks to the kindness of Dr. Williams of the Obstetrical Department, we were able to collect about 1,900 c.c. of urine from normal breast-fed infants. The amount obtained from the different babies was as follows:

\begin{tabular}{|c|c|c|c|}
\hline $\begin{array}{l}\text { Infant } \\
\ldots \ldots\end{array}$ & $\begin{array}{c}\text { Collection started, } \\
\text { days after birth }\end{array}$ & $\begin{array}{c}\text { Urine Collected, } \\
\text { days }\end{array}$ & $\begin{array}{l}\text { Amount collected, } \\
\text { c.c. }\end{array}$ \\
\hline $\begin{array}{ll}1 & \ldots \\
2 & \ldots \\
3 & \ldots \\
4 & \ldots\end{array}$ & $\begin{array}{cc}\ldots \ldots & 10 \\
\ldots \ldots \ldots & 6 \\
\ldots \ldots \ldots & 6 \\
\ldots \ldots \ldots & 23\end{array}$ & $\begin{array}{l}2 \\
6 \\
6 \\
2\end{array}$ & $\begin{array}{l}409 \\
426 \\
914 \\
162\end{array}$ \\
\hline & & & 1,911 \\
\hline
\end{tabular}

\footnotetext{
*From the Department of Pediatrics and the Department of Pharmacology, Johns Hopkins University.

1. Mayerhofer: Chemische Teilerscheinungen im Harne gesunder und kranker Säuglinge, Ztschr. f. Kinderh., 1911, i, 487.

2. Marchant: Ueber die Oxydationsproducte des Leims, etc., Jour. f. pract. Chem., 1845, xxxv, 309.

3. Meissner and Shephard: Untersuchungen über das Entstehen der Hippursäure; Hanover, 1866.

4. Amberg and Morrill: Ein Stoffwechselversuch, ete., Jahrb. f. Kinderh., 1909, Ixix, 280.
} 
The babies had surpassed their birth weight when the urine was collected and were in perfect condition clinically. To exclude the possibility of slight digestive disturbances 10 c.c. of each sample of urine was used for the determination of phosphoric acid. Moll ${ }^{5}$ has shown that the amount of phosphoric acid excreted in the urine of breast-fed infants may serve to indicate very slight digestive disturbances. Only such urine was used as corresponded to the standard established by Moll for the urines of the class "free from phosphates." Therefore we have reason to assume that the urine examined by us was obtained from perfectly healthy individuals.

The method of analysis employed is that of Jaarsveld and Stokvis, ${ }^{6}$ which was retested by Van de Velde and Stokvis. ${ }^{\text {? }}$

It is not our purpose to discuss here the literature concerning the occurrence of hippuric acid in the urine of animal and man under different conditions, nor the various methods for its determination. References to the literature may be found in the report of the United States Department of Agriculture. ${ }^{8}$

Each portion of urine was immediately evaporated to a small volume with the addition of some sodium carbonate, transferred to a flask and preserved with toluol until the total amount was collected. The method of analysis may be described briefly. The urine evaporated to a small volume is acidified with hydrochloric acid and thoroughly extracted with acetic ether after standing twenty-four hours. The acetic ether extract is washed with water and evaporated at room temperature, the residue containing free and combined benzoic acid, if any is present. The free benzoic acid is extracted with petrol ether. The residue is hydrolyzed by boiling with strong sodium hydroxid, thus liberating the benzoic acid from hippuric acid. After cooling, the fluid is acidified with hydrochloric acid and after standing over night, thoroughly extracted with petrol ether. This extract is evaporated at room temperature, leaving the benzoic acid.

Examined by this method, the urine did not show any crystals on evaporation of the acetic ether extract, nor was any benzoic acid found after the hydrolysis of the residue from this extract. There was no evidence of the presence of either free or combined benzoic acid. As with other methods of hippuric acid determination in urine, small amounts may escape detection. We may mention the statement of Wiechowski ${ }^{9}$

5. Moll: Die klinische Bedeutung, etc., Jahrb. f. Kinderh., 1909, lxix, 129.

6. Jaarsveld and Stokvis: Ueber den Einfluss der Nierenaffectionen, etc., Arch. f. exper. Path. u. Pharm., 1879, x, 268.

7. Van de Velde and Stokvis: Experimentelle Beiträge, etc., Arch. f. exper. Path. u. Pharm., 1883, xvii, 189.

8. The Influence of Sodium Benzoate on the Nutrition and Health of Men, Bull. 88, U. S. Dept. Agriculture, 1909.

9. Wiechowski: Die Gesetze der Hippursäuresynthese, Beitr. z. chem. Physiol. u. Path., 1906, vii, 204. 
that the method of Jaarsveld and Stokvis gives good results even in the presence of small amounts of hippuric acid.

Since the question of the presence or absence of hippuric acid in the urine of the normal breast-fed infant is of considerable interest, it would have been desirable to extend our investigations with the employment of different methods of analysis, but we were unable to obtain the necessary amount of urine. Nevertheless, from the result just recorded it does not seem probable that a very appreciable part of the nitrogen contained in the urine of the normal breast-fed infant is excreted in the form of hippuric acid.

The character of the food-mother's milk, with its content of lactalbumin-is such that it could supply sufficient glycocoll for the formation of hippuric acid. But even if the food should not yield glycocoll on decomposition, this substance could be furnished by the animal organism. For instance, Grosser, ${ }^{10}$ feeding young goats with casein and giving benzoic acid, found hippuric acid in the urine. Furthermore, Brugsch and Hirsch, ${ }^{11}$ as well as Feigin, ${ }^{12}$ found hippuric acid in the urine of hunger artists. To demonstrate that the normal breast-fed infant can readily furnish glycocoll, such a baby received $0.5 \mathrm{gm}$. of sodium benzoate. During the next twenty-four hours 175 c.c. of urine were collected, yielding, on evaporation of the acetic ether extract, hippuric acid.

The absence of demonstrable amounts of hippuric acid from the urine of the normal breast-fed infant depends, therefore, on the absence of benzoic acid. Most authors agree that the benzoic acid normally entering into the production of hippuric acid in man is either derived from benzoic acid or related substances contained in food, or from putrefactive processes in the intestinal canal. ${ }^{13}$ Since it is known that putrefactive processes are, as a rule, in abeyance in the intestinal canal of perfectly normal breast-fed infants, the absence of hippuric acid from the urine would not be surprising. Quite recently Simon, ${ }^{14}$ using the method of Henriques and Soerensen, ${ }^{15}$ claims to have demonstrated the presence of hippuric acid in the urine of the breast-fed infant. In this method the hippuric acid is also extracted with acetic ether. The residue is

10. Grosser: Beitrag zur Bewertung des Albumingehalts, etc., Jahrb. f. Kinderh., 1911, lxxiii, 103.

11. Brugsch and Hirsch: Gesammt N, etc., Ztschr. f. exper. Pathol. u. Therap., 1906, iii, 638 .

12. Feigin: Ueber die Hippursäurenscheidung, etc., Inaugural dissertation, Berlin, 1906.

13. See, for instance, Baumann: Die aromatischen Verbindungen, etc., Ztschr. f. physiol. Chem., 1886, x, 123; Gerhardt: Ueber Darmfäulniss, Ergebn. d. Physiol., 1904, iii, 138.

14. Simon: Zur Stickstoffverteilung im Urin des Neugeborenen, Ztschr. f. Kinderh., 1911, ii, 1.

15. Henriques and Soerensen: Ueber die quantitative Bestimmung, etc., Ztsch. f. physiol. Chem., 1909, 1xiii, 27. 
decomposed with hydrocholoric acid and the nitrogen of the resulting glycocoll is determined by means of the formol titration. In the first three days after birth the hippuric acid excretion was found to be rather high, running later on a lower level. The lowest figure was found on the eighth day (case Brunner), when 225 c.c. of urine yielded $0.005 \mathrm{gm}$. of nitrogen, corresponding to $0.0639 \mathrm{gm}$. of hippuric acid. The urine of our infants was collected later than the third day after birth; that is, when the excretion of hippuric acid has reached a lower level. If we calculate the amount of hippuric acid that should be present in the 1,911 c.c. of urine, using the lowest figure given by Simon, we should have $0.543 \mathrm{gm}$. of hippuric acid, or $0.37 \mathrm{gm}$. of benzoic acid. It is very unlikely that the urine examined by us should have contained an amount of hippuric acid approaching such a figure. 